\title{
SOSIALISASI BUDAYA MALU DI KALANGAN PELAJAR MELAUI INFOGRAFIS SEBAGAI BENTUK PENDIDIKAN KARAKTER
}

\author{
Fitria Iswari, Dian Handayani, Widya Nuriyanti
}

\author{
Program Studi Desain Komunikasi Visual \\ Fakultas Bahasa dan Seni, Universitas Indraprasta PGRI \\ Jl. Nangka 58 Tanjung Barat, Jakarta Selatan, Indonesia \\ fitriaiswari@gmail.com,dian.zulaikhasaja@gmail.com,widyanuriyanti@gmail.com
}

\begin{abstract}
Abstrak
Pelajar adalah pemuda penerus bangsa, namun apa yang terjad iapabila rendahnya budayamalu yang dimiliki oleh para pelajar. Banyak pelanggaran yang dilakukan oleh siswa seperti terlambat datang ke sekolah, membuang sampah sembarangan, tidak hormat kepada guru, berpakaian tidak rapi, berbicara kotor dan yang lainnya. Hal tersebut menunjukkan bahwa rendahnya budaya malu para pelajar saat ini. Hal tersebut menjadi perhatian karena ini berarti pendidikan karakter yang belum sepenuhnya terserap oleh para pelajar. Pendidikan karakter kepada peserta didik. Karena sejatinya Pendidikan berkarakter saat ini diharapkan mampu membentu kwatak, kebiasaan, dan tingkah laku para pelajar kearah yang lebih baik. Tulisan ini membahas tentang penggunaan infografis sebagai media soaialisasi budaya malu sebagai bentuk pendidikan karakter. Hal ini bertujuan untuk meningkatkan budaya malu siswa dan terbentuknya karakter yang lebih baik. Tulisan in imenggunakan metode yang kualitatif dengan cara observasi dan menyelenggarakan FGD (focus group discussion) yang melibatkan kepala sekolah, wakil, staff kesiswaan, guru bimbingan konseling, dan beberapa guru. Hal tersebut dilakukan untuk member gambaran tentang perilaku siswa SMPN 64 Jakarta, dan merumuskan materi yang gunakan pada infografis. Teknik pengumpulan data dengan cara wawancara kepada staff kesiswaandan guru BK. Selanjutnya infografis tersebut pajang di depan sekolah sebagai media sosialisasi budaya malu. Hasil dari penggunaan media selama 1 bulan ini berdampak positif, yaitu dengan ditunjukan berkurangnya peserta didik yang terlambat, berpakaian tidak rapi, membuang sampah sembarangan, berbicara kotor, dan tidak sopan dengan guru. Hal ini menunjukan media sosialisasi budaya malu berupa infografis berhasil membentuk karakter para siswa ke arah yang lebih baik.
\end{abstract}

Kata Kunci : Media Sosialisasi, Infografis, BudayaMalu, Pendidikan karakter.

\begin{abstract}
Student is a person who develops the country, but what will be happen if they have low ashamed culture. There are many rules that are broke by students for example: coming late to school, littering, impolite to teacher, faultlessly dressed, saying rudeness, and etc. It shows learners have low ashamed culture. It is be a highlight because it means the character education has not been master by students. Actually character education can build better character, habit, and manner of students. This paper explains the using of infographic as socialization media of ashamed culture that is a part of character education. It has purpose to increase the students' ashamed culture and build a better character. This paper uses qualitative method by using observation trough FGD (Focus Group Discussion) that involves head master and vice, student board staff, counsellor, and some teachers. It is done in order to give information about the students' behaviour, and to arrange the material that will be used in infographic. The data are taken by doing interview to counsellor and student board staff. Then the infographic will be put in front of entrance of the school as socialization media of ashamed culture. The using of infographic in a month gives the positive result that is shown by reducing of students that come late, litter, say rudeness, impolite to teachers. It means the socialization media or infographic is success to build better students character.
\end{abstract}

Keywords: Socialization media, Infographic, Ashamed culture, Character education. 


\section{PENDAHULUAN}

Indonesia adalah salah satu negara yang menjunjung budaya malu. Saat ini budaya malu di kalangan pelajar menunjukan kecenderungan semakin berkurang. Hal tersebut ditandai dengan banyaknya pelanggaran yang dilakukan pelajar di sekolah. Perilaku menyimpang yang seringdilakukan pelajar tersebut cenderung pada perilaku yang tidak sesuai peraturan yang dibuat oleh sekolah. Contohnya terlambat datang ke sekolah seperti berita yang dilansir pada kompas harian.com yang mencatat bahwa Pada hari pertama masuk sekolah tahun ajaran 2016/2017, Senin (18/7/2016), belasan pelajar SMAN 3 Jakarta terlambat datang ke sekolah saat mereka datang, gerbang masuk sekolah sudah ditutup dan upacara sudah dilangsungkan. Dari kutipan berita di atas terlihat bahwa masih rendahnya budaya malu di kalangan pelajar. Hasil temuan Ridho Ilahi dalam artikel dalam Jurnal Ilmiah Konseling UNP bahwa faktor yang mempengaruhi pelanggaran disiplin siswa di SMA N X Padang yang dipaparkan sebelumnya, dapat diketahui bahwa yang berpengaruh terhadap pelanggaran disiplin siswa pada faktor internal adalah dari segi segi kondisi psikologis (perhatian, minat, motivasi, keterampilan belajar, dan kematangan). Hal ini menjadi indikasi bahwa masih rendahnya kharakter para pelajar sehingga berimbas pula pada budaya malu yang dimiliki.

Selain terlambat tidak mengerjakan pekerjaan rumah dan menyontek masih marak di kalangan pelajar. Sebagaimana yang dilansir media sindonews (diunduh pada 1 september 2016) Hari kedua pelaksanaan Ujian Nasional (UN) tingkat SMP di Polewali Mandar, Sulawesi Barat, diwarnai sejumlah aksi curang oleh siswa dengan saling menyontek. Ironisnya, aksi curang ini tak terpantau pengawas. Aksi saling menyontek itu terekam dalam UN hari kedua di SMPN 6 Polewali Mandar. Mereka berhenti menyontek ketika sadar terekam kamera wartawan, dan masih banyak perilaku pelajar yang minim rasa malu seperti tidak mengerjakan PR, berbicara kasar, hingga membuang sampah sembarangan di lingkungan sekolah. Berita tersebut adalah sebagian contoh dari merosotnya budaya malu di kalangan pelajar yang sebaiknya kita sikapi.

Pendidikan berkarakter diharapkan mampu membentuk, kebiasaan, watak dan tingkah laku para pelajar kearah yanglebih baik. Sekolah melalui para pendidik sudah selayaknya mengintegrasi nilai-nilai pendidikan yang terbaik bagi siswa. Hal ini bertujuan untuk membiasakan siswa berperilaku sesuai dengan etika sosial.

Dalam hal ini sekolah membutuhkan media sosialisasi diluar peraturan peraturan yang diterapkan di sekolah. Salah satunya melalui pesan sosial berupa infograsis. Pesan sosial adalah sebagian bentuk dari pendidikan karakter. Pesan yang membawa makna sosial ini diharapkan mampu memberi informasi tentang budaya malu yang diharapkan mampu member kontribusi sebagai pendidikan karakter melalui media.

Seperti yang diungkapkan oleh Emilia Susanti dalam Artikel yang berjudul "Budaya Malu Cerminan Bagi Perempuan Melayu" mengungkapkan bahwa jika budaya malu telah bisa kita pegang pada zaman yang semakin perkembang ini tentu tindakan kriminal dan terutamanya bagi perempuan akan berkurang dan akan lebih terjaga. Dari kalimat tersebut tersirat bahwa hilangnya budaya malu dapat menjurus pada perilaku yang menyimpang

Dalam budaya Jepang, Benedict (1982:172) mengungkapkan bahwa perasaan bersalah merupakan perwujudan dari nilai moral antara baik dan buruk. Sementara perasaan maluhadir pada saat orang lain mengevaluasi diri kita. Dalam Hamid, Chadijah juga melakukan penelitian kepada masyarakat Bugis Makasar yang ditemukan bahwa masyarakat Bugis-Makasar yang dikenal dengan siri' membentuk suasana hati seseorang 
yang bersangkutan dengan harga diri pada saat terjadi pelanggaran norma atau nilai social (Hamid,dkk.2007:5) mempertahankan harga diri respon dari rasa malu. Dalam siri' terdapat nilai-nilai moral untuk mempertahankan harga diri orang yang menganutnya.

\section{Pesan Sosial}

Penyampaian pesan tentang budaya malu termasuk pesan sosial. Pesan sosial dapat disampaikan dalam berbagai bentuk, melalui tulisan, gambar, atau bahkan film.Prof. Dr. Notonegoro yang ditulis oleh Denny Pratama Putra (2014) dalam penelitian Makna Pesan Sosial Dalam Film FREEDOM WRITERS (Analisis Semiotika). Fakultas Ilmu Sosial dan Politik. Universitas Hasanudin : Makasar membagi nilai menjadi tiga macam sebagai berikut.

1. Nilai material

2. Nilai vital

3. Nilai kerohanian

Pengklasifikasian nilai-nilai sosial diatas kemudian diwujudkan dalam sebuah pesan. Pesan inilah yang dikenal sebagai pesan sosial. Pesan sosial dalam penelitian ini berupa model infografis statis yang dipasang di lingkungan sekolah sebagai bentuk dari pendidikan karakter.

Sosialisasi adalah proses yang membutuhkan orang lain guna mendapatkan kemampuan interaksi yang baik. Sosialisasi tidak mungkin terjadi hanya pada individu, melainkan melibatkan pihak lain.

Wilbur Schramm dalam Ibnu Hamad (2010) menampilkan apa yang disebut dengan "the condition of success in communication", yakni kondisi yang harus dipenuhi jika kita menginginkan agar suatu pesan membangkitkan tanggapan yang kita kehendaki. Kondisi tersebut dapat dirumuskan sebagai berikut:

1. Pesan harus dirancang dan disampaikan sedemikian rupa, sehingga dapat menarik perhatian komunikan.

2. Pesan harus menggunakan lambang-lambang tertuju kepada pengalaman yang sama antara komunikator dan komunikan, sehingga sama-sama mengerti.

3. Pesan harus membangkitkan kebutuhan pribadi komunikan dan

4. Menyarankan beberapa cara untuk memperoleh kebutuhan tersebut.

5. Pesan harus menyarankan suatu jalan untuk memperoleh kebutuhan tadi yang layak bagi situasi kelompok di mana komunikan berada pada saat ia digerakkan untuk memberikan tanggapan yang dikehendaki.

Infografis merupakan singkatan dari "grafis informasi". Sebagian orang menggunakan istilah ini untuk dapat mengartikan format unik yang telah digunakan secara luas untuk aplikasi ini, yang dicirikan dengan ilustrasi, tipografi besar, dan orientasi memanjang, vertical yang menampilkan berbagai fakta (Lankow, J, dkk. 2014: 20). Selain itu diterangkan juga perbedaab antara inforgrafis statis dan bergerak, yaitu : Infografis statis biasanya informasi tetap. Interaksi pengguna mencakup melihat dan membaca. Yang ditampilkan ialah cerita diam. Paling baik sebagai narasi meskipun bisa juga exsploratif. Sementara Infografis bergerak biasanya informasi tetap. Interaksi pengguna terdiri atas melihat, mendengarkan jika ada narator di belakang dan membaca. Paling baik sebagai narasi, hampir tidak pernah eksploratof kecuali digunakan bersama konten interaktif.

Berikut ini tiga ketentuan dasar untuk semua metode komunikasi verbal atau visual yang efektif, yaitu: (Lankow, dkk. 2014: 30) 
1. Daya Pikat

Komunikasi harus terjalin dengan audiens secara sukarela.

2. Komprehensi

Komunikasi harus dengan efektif menyediakan pengetahuan yang memungkinkan pemahaman yang jelas atas informasi.

3. Retensi

Komunikasi harus tidak mudah dilupakan.

Manfaat dari penggunaan infografis dalam komunikasi adalah usaha membantu orang mengingat informasi. Visualisasi melakukannya dengan secara seketika dan terus menerus menggambarkan informasi nonvisual yang tersimpan dalam memori jangka panjang Ware dalam Lankow, dkk (50: 2014).

\section{Budaya Malu di Kalangan Pelajar}

Kata budaya berasal dari bahasa sansekerta yaitu buddayah yang dapat diartikan sebagai hal - hal yang berkaitan dengan budi, dan akal manusia. Konsep kebudayaan menurut Koentjaraningrat (dalam Takari, dkk, 2008:5) adalah keseluruhan system gagasan, tindakan dan hasil karya manusia dalam rangka kehidupan masyarakat yang dijadikan milik manusia dengan belajar. Kebudayaan erat hubungannya dengan masyarakat dan kehidupannya. Budaya tercipta memalui tingkah laku dan pola pikir masyarakat. Menurut Soemardjan dan Soemardi (dalam Soekanto, 2007) kebudayaan adalah sebagai semua hasil karya, rasa dan cipta masyarakat. Karya masyarakat menghasilkan teknologi dan kebudayaan kebendaan atau kebudayaan jasmaniah (material culture) yang diperlukan oleh manusia untuk menguasai alam sekitarnya agar kekuatan serta hasilnya dapat diabdikan untuk keperluan masyarakat.

Pengertian kebudayaan dapat dibedakan menjadi dua, yaitu kebudayaan dalam arti luas dan sempit (Ienaga Saburo dalam Situmorang, 2006:2-3). Dalam arti luas kebudayaan adalah seluruh cara hidup manusia (ningen no seikatsu no itonami kata) dan tidak bersifat alamiah. Sedangkan kebudayaan dalam arti sempit adalah keseluruhan hal yang terdiri dari tradisi, ilmu penegetahuan, system kepercayaan dan seni. Oleh karena itu Ienaga mengatakan kebudayaan dalam arti luas adalah segala sesuatu yang bersifat konkrit yang diolah manuasia untuk memenuhi kebutuhannya. Sedangkan dalam arti sempit budaya sesuatu yang berisifat semiotik.

Kebudayaan sangat penting dalam kehidupan bermasyarakat, maju tidaknya suatu negara tergantung dengan budaya masyarakat suatu negara tersebut. Belakangan ini budaya malu di kalangan pelajar mulai menurun, budaya negatif seperti menyontek, tidak berpakaian rapi, datang terlambat, dan yang lainya dianggap sebagai hal yang lumrah yang sering disebut sebagai kenakalan remaja. Crow and Crow dalam Siti Meichati (2002: 154) yang ditulis Dwi Endro Lestari dalam mengemukakan bahwa: "Bentuk pelanggaran tata tertib yang sering dilakukan siswa antara lain berupa terlambat datang ke sekolah, berkirim surat, membantah perintah, melalaikan tugas, membolos, berisik dalam kelas, ribut, ceroboh dalam tindakan, merusak benda-benda, nakal (berkelahi), marah, bersikap asusila". Budaya malu mengenai hal yang sangat sederhana seperti membuang sampah pada tempatnya menjadi budaya yang semakin lama semakin luntur dan menjadi hal yang sudah biasa apabila membuang sampah di sembarang tempat.Menurut Barret ( dalam Tangney 1995 : 1134) mengatakan bahwa sosialisasi dan internalisasi nilai dan norma sosial ke dalam diri individu ditentukan oleh sejauh mana kontribusi faktor sosiokultural dalam pembentukan emosi khususnya emosi kesadaran diri yang berkenaan dengan rasa malu dan bersalah. Dalam hal ini dapat dikatakan tinggi rendahnya budaya malu 
ditentukan oleh, perilaku, kebiasaan, dan control sosial terhadap budaya malu itu sendiri. Dengan adanya pesan sosial ini mampu memepengaruhi nilai material yang berhubungan dengan jasmani, nilai vital yang mempengaruhi kegiatan manusia, serta nilai kerohanian ya.ng berguna bagi batin (rohani) manusia

Rasa malu artinya mengutamakan penilaian masyarakat pada umumnya. Perasaan malu timbul pada saat orang lain menilai diri kita. Rasa malu yang pudar di kalangan pelajar ini menurun dengan diikuti oleh permasalahan para siswa di sekolah. Menurut artikel yang ditulis Emilia Susanti (UIN Sutan Syarif Kasim Riau.Sosial Budaya: Media Komunikasi Ilmu, vol 11,No 2 Juli-Desember 2014) bahwa becara umum, ada tiga jenis malu yaitu;

1. Malu kepada Allah

2. Malu kepada sesama manusia

3. Malu kepada diri sendiri

\section{Pendidikan Karakter}

Pendidikan karakter saat ini banyak digunakan dalam kurikulum KTSP maupun KURTILAS (kurikulum 2013). Pengertian karakter menurut Pusat Bahasa Depdiknas adalah "bawaan, hati, jiwa, kepribadian, budi pekerti, perilaku, personalitas, sifat, tabiat, temperamen, watak". Dengan itu karakter dapat didefinisikan sebagai landasan kepribadian yang meliputi akhlak, watak, dan tabiat sebagai acuan dalam bertindak di kehidupan sehari - hari .

Menurut Megawangi (dalam Kesuma, dkk 2011:5) Pendidikan karakter adalah sebuah usaha untuk mendidik anak-anak agar dapat mengambil keputusan dengan bijak dan mempraktikkanya dalam kehidupan sehari-hari, dan mampu member hal positif pada lingungannya. Guru membantu membentuk watak peserta didik. Oleh karena itu pendidikan karakter adalah dilakukan bersama untuk mendidik watak dan kepribadian agar berperilaku bijak dan positif dalam lingkungannya.

Berdasarkan pendapat Zubaedi (2011:18) bahwa pendidikan karakter memiliki tiga fungsi utama. Pertama, fungsi pembentukan dan pengembangan potensi. Pendidikan karakter berfungsi untuk menciptakan siswa dengan watak, kepribadian dan tingkah laku yang baik. Kedua, fungsi perbaikan dan penguatan. Pendidikan karakter sebagai penguat dalam kehidupan rumah tangga, lingkungan masyarakat, dan negara. Ketiga, fungsi penyaring. Pendidikan karakter menjadi penyaring budaya sendiri dan budaya orang lain.

Mulyasa (2011: 4) menekankan pentingnya tiga komponen karakter yang baik, komponen tersebut diantaranya yaitu moral knowing (pengetahuan tentang moral), moral feeling (perasaan tentang moral), dan moral action (tindakan moral). Dalam hal ini tugas para pendidik adalah menciptakan lingkungan yang nyaman, memberikan aktivitas yang positif dan memberikan motivasi yang tinggi agar para siswa berperilaku yang baik. Pendidikan karakter untuk remaja dilakukan untuk menanamkan nilai kedisiplinan, rasa hormat, kejujuran, dan tolong menolong.

Tulisan ini membahas tentang penggunaan media sosialisasi berupa infografis yang berisiskan tentang budaya malu untuk digunakan di SMP 64 Jakarta guna mengingatkan para pelajar akan pentingnya budaya malu sebagai salahsatu bentuk pendidikan karakter. Diharapkan dengan diadakannya penelitian ini akan mampu memberikan informasi budaya malu apa saja yang sering dilanggar di kalangan pelajar sehingga mereka tau dan merasa malu kemudian mampu menjadi siswa yang berkarakter dengan berubah sikap menjadi lebih baik. 


\section{METODE PENELITIAN}

Lokasi penelitian adalah di SMPN 64 Jakarta, tepatnya di JalanKarang Anyar no 11-12 Jakarta Pusat. Dalam penelitian ini menggunakan pendekatan kualitatif. Menurut Jane Richie (Moleong, 2006: 6), dari kajian tentang berbagai definisi penelitian kualitatif, dapat disintesiskan bahwa penelitian kualitatif adalah penelitian yang bermaksud untuk memahami fenomena tentang apa yang dialami oleh subjek penelitian seperti perilaku, persepsi, motivasi, tindakan, dan lain-lain, secara holistic dan dengan cara deskripsi dalam bentuk kata-kata dan bahasa., dan menggunakan metode Focus Group Discussion (FGD). Maka metode FGD dengan melibatkan Kepala sekolah, wakil kepala sekolah, guru Bimbingan Konseling, staff kesiswaan, dan beberapa walikelas guna mendapatkan informasi tentang keadaan siswa di sekolah tersebut.

1. Brainstorming tentang materi yang akan disajikan dalam infografis budaya malu.

2. Konsultasi untuk infografis yang akan digunakan.

Teknik analisis data pada penelitian ini menggunakan metode analisis model Miles Huberman (1962:16) di mana secara umum proses analisis data setelah dibaca, dipelajari, dan ditelaah, kemudian selanjutnya data direduksi, disajikan, dan ditarik kesimpulan dan verivikasi. Periode yang diterapkan dalam penelitian ini adalah 4 bulan dengan sosialisasi selama 1 bulan dan kemudian diamati hasil 1 bulan setelah sosialisasi.

\section{HASIL DAN PEMBAHASAN}

Insight yang didapat dari literatur dan wawancara mendalam disepakati bahwa icon-iconyang digunakan mengarah kepada karakter usia pelajar baik untuk laki-laki maupun perempuan, yaitu pelajar dengan menggunakan pakaian seragam biru. Penggunaan warna dan karakter huruf (tipografi) juga disepakati warna - warna yang mengarah kepada usia remaja, penggunaan bahasa mengarah kepada bahasa yang sering digunakan sehari-hari oleh usia remaja. Infografis statis dalam bentuk banner berukuran 1,5 x $2 \mathrm{~m}$ yang akan dipasang di papan pengumuman di dekat pintu masuk sekolah. Di harapkan pesan sosial yang diletakan di dekat pintu masuk dapat terlihat dan dibaca oleh seluruh pelajar.

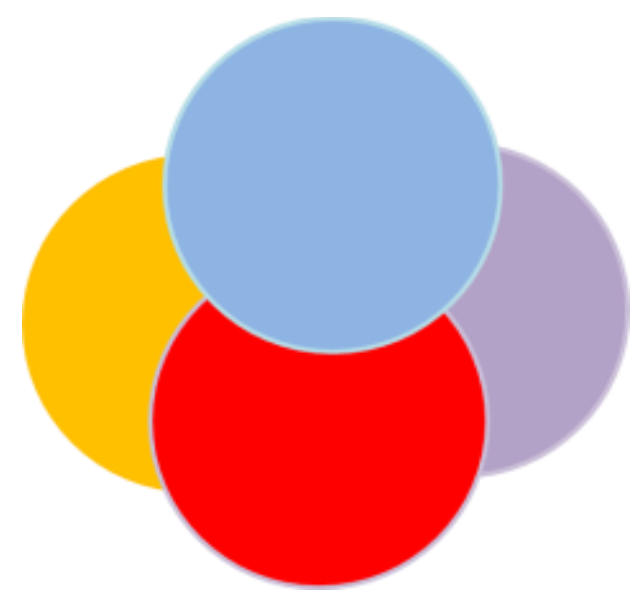

Gambar 1 Penggunaan Warna 


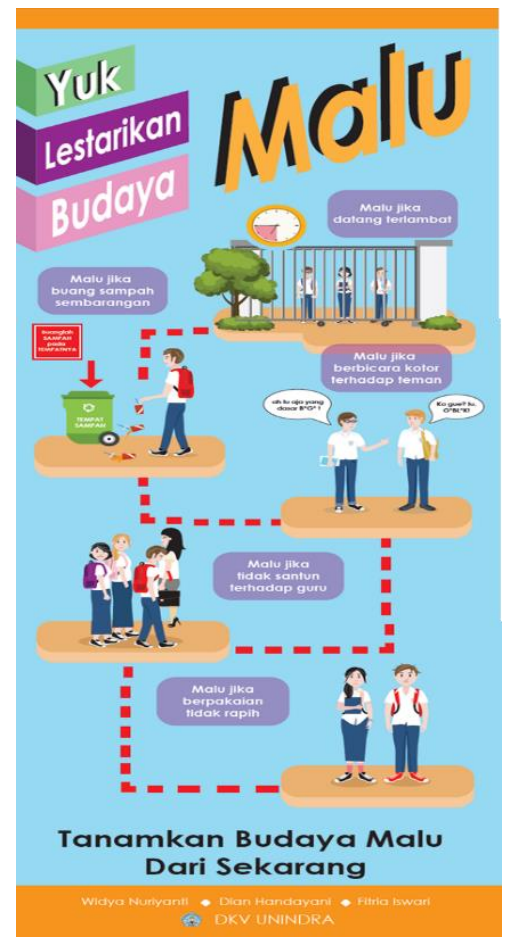

Gambar 2

Infografis Budaya Malu Di Kalangan Pelajar

\section{Pesan Sosial dalam infografis statis}

Pesan sosial yang dibuat untuk sebagai pesan sosial sebagai media sosialisasi budaya malu di kalangan pelajar dengan memperhatikan pada khalayak yang dituju yaitu usia muda. Karakter dari ikon yang dibuat mengarah kepada gaya hidup remaja masa kini yang mulai memudar rasa malu di kalangan pelajar terutama terhadap hal yang negatif. Makna gambar yang dibuat dalam pesan sosial dibuat berdasarkan hasil FGD (Focus Group Discussion) bersama kepala sekolah,wakil, staff kesiswaan, dan beberapa tenaga pendidik. Dari hasil diskusi tersebut disimpulkan urutan pelanggaran yang sering dilakukan oleh para siswa yang kemudian kami buat dalam infografis statis tersebut. Gambar yang ditetapkan dalam infografis adalah 5 hal negatif yang sering dilakukan oleh siswa. Kelebihan penggunaan infografis statis ialah mudahnya pembuatan citra, lebih efisien dan terjangkau, serta mudah dibagi-bagikan. Berikut tabel dan penjelasan pesan gambar infografis.

Tabel 1. Makna Gambar Infografis

Icon

Makna

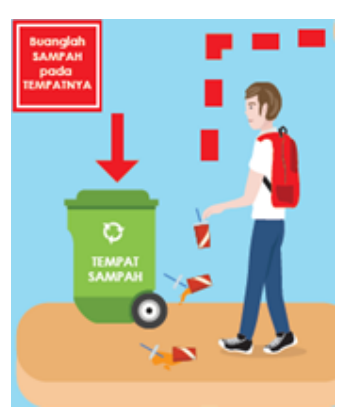

Pelajar sedang buang sampah tidak pada tempatnya meskipun terdapat tempat sampah di hadapannya. 

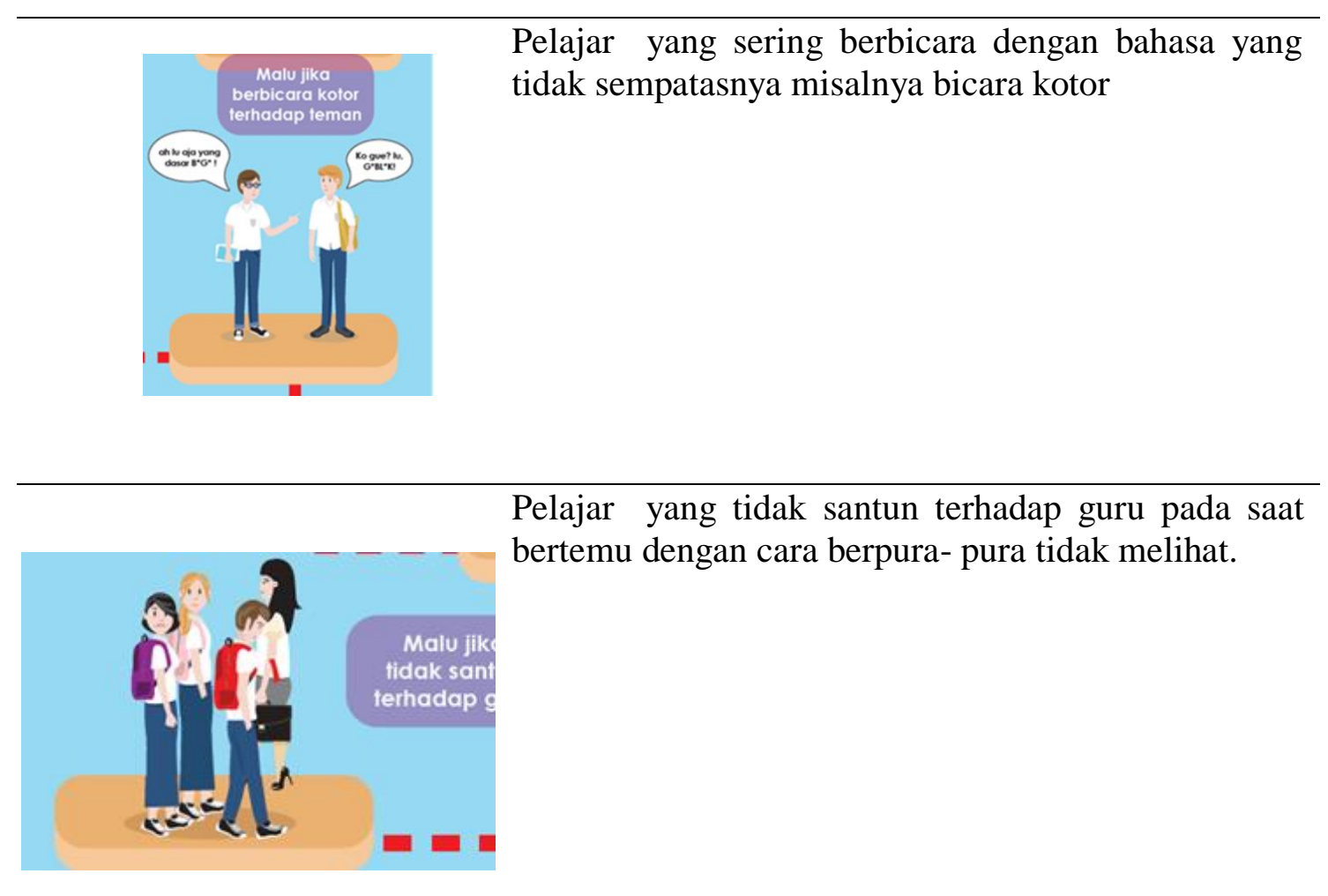

Pelajar yang tidak santun terhadap guru pada saat bertemu dengan cara berpura- pura tidak melihat.

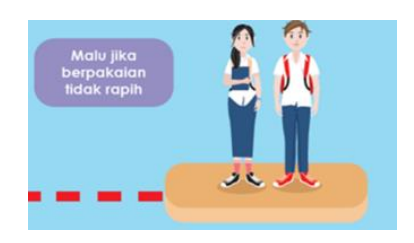

Pelajar yang berpakaian tidak lengkap dan tidak rapih.

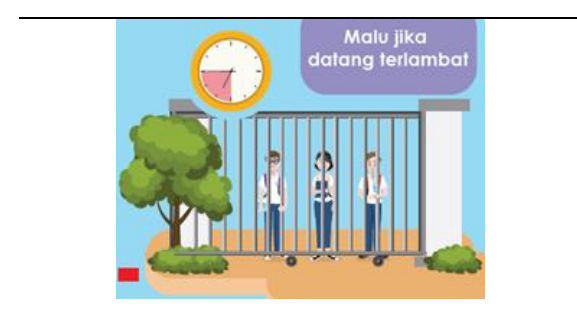

Para siswa yang datang terlambat ke sekolah maka pihak sekolah mengunci gerbang sehingga para siswa tidak bisa masuk.

Tanamkan Budaya Malu Dari Sekarang
Kalimat persuasif ditulis dengan warna gelap diharapkan mampu dibaca siswa dengan lebih mudah

\section{Budaya Malu di Kalangan Pelajar SMP 64 Jakarta.}

Berdasarkan data yang didapat dari hasil FGD (Focus Group Discussion) bersama bapak kepala sekolah, staff dan pengajar. Ditemukan beberapa sikap negatif para siswa yang dilakukan dan berulang-ulang kali yang disajikan dalam presentasi berbentuk diagram batang. 


\section{Bagan 1. Persentase}

Perilaku Negatif Siswa.

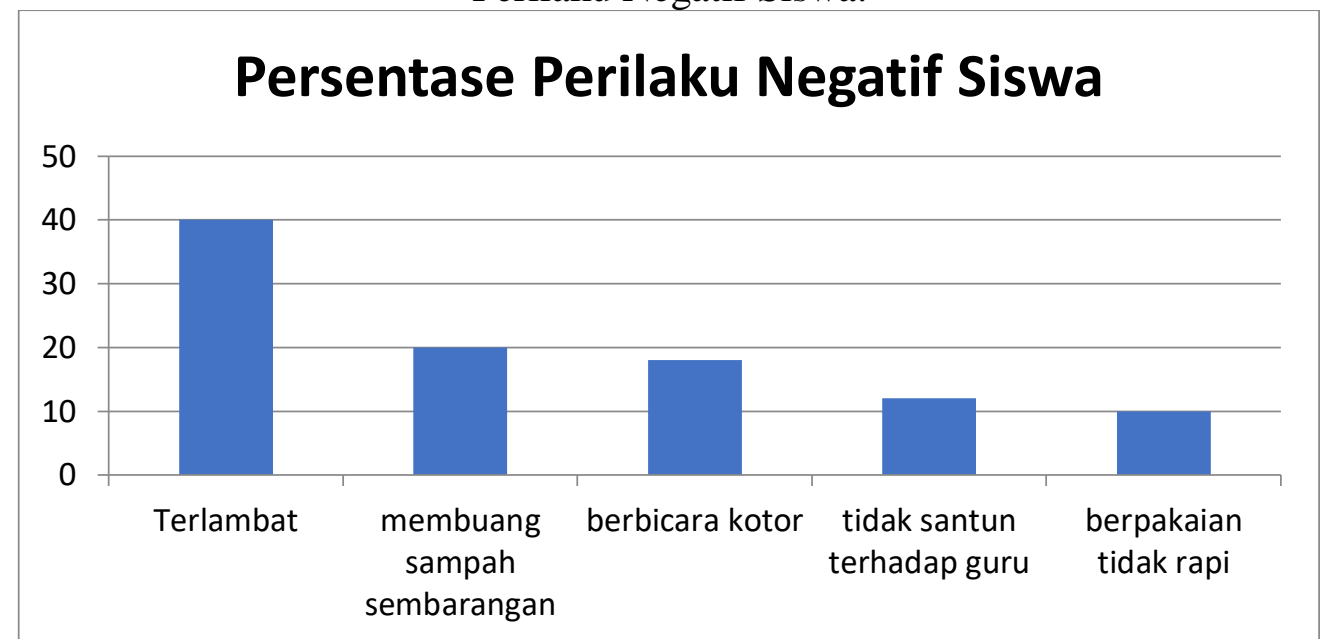

Dalam temuan tersebut terlihat bahwa budaya malu para peserta didik masih rendah. Hal ini ditandai dengan beberapa pelanggaran, yaitu terlambat menjadi pelanggaran yang sering dilakukan peserta didik yaitu sebanyak $40 \%$, selanjutnya tempat ke-2 ialah membuang sampah sembarangan sebanyak $20 \%$, berbicara kotor ternyata menjadi urutan ke 3 dengan persentase $18 \%$, perilaku tidak santunterhadap guru menempati tempat ke-4 sebanyak $12 \%$, yang terakhir berpakaian tidak rapi ditandai dengan tidak lengkapnya atribut sekolah sebanyak $10 \%$. Terutama budaya malu akan datang terlambat. Bel sekolah berbunyi pukul 06.30 WIB, diberikan 15 menit tenggang waktu. Apabila peserta didik belum juga hadir pada pukul 06.45 maka gerbang akan ditutup dan siswa akan menunggu hingga jam mata pelajaran ke-2 dimulai, atau ada sebagian dari mereka dipulangkan akibat terlalu sering terlambat dan diberikan surat peringatan. Selanjutnya urutan kedua adalah hobi akan buang sampah sembarangan. Para peserta didik seakan-akan tidak memiliki rasa malu atau bersalah sudah mengotori lingkungan. Yang ketiga berbicara kotor terhadap teman, dan keempat tidak santun terhadap guru, urutan terakhir tidak malu berpakaian tidak rapi. Dari uraian tersebut dibutuhkannya sosialisai tentang berbudaya malu sebagai bentuk dari pendidikan karakter.

Pesan infografis tersebut dipajang di depan sekolah setelah gerbang yang setiap harinya akan dilihat oleh para peserta didik. Dari pantauan guru BK perilaku negatif siswa menurun. Hal ini ditandai dengan berkurangnya siswa yang terlambat, ruangkelas menjadi bersih karena berkurangnya preserta didik yang membuang sampah sembarangan. Berikut data yang diambi 1 dari buku kasus guru bk selama 1 bulan.

\begin{tabular}{|l|c|c|}
\hline Keterangan & $\begin{array}{c}\text { Sebelum } \\
\text { Penggunaan infografis }\end{array}$ & $\begin{array}{c}\text { Sesudah } \\
\text { Penggunaan infografis }\end{array}$ \\
\hline Terlambat & 40 & 10 \\
\hline Buang sampah sembarangan & 15 & 5 \\
\hline BerbicaraKotor & 38 & 10 \\
\hline Tidak Santun terhadap guru & 5 & 0 \\
\hline Berpakaian tidak rapi & 20 & 5 \\
\hline
\end{tabular}

Dari data tersebut terlihat bahwa penggunaan infografis sebagai media sosialisai budaya malu sebagai bentuk pendidikan karakter dianggap berhasil .Hal ini ditunjukan 
oleh perubahan sikap para peserta didik yang lebih bai dan ini ditandai dengan menurunnya persentase kasus terlambatnya siswa sebanyak $75 \%$, buang sampah sembarangan sebanyak $33 \%$, berbicara kotor $26 \%$, tidak santun terhadap guru mencapai $100 \%$, dan berpakaian tidak rapi menurun $25 \%$. Berdasarkan buku catatan kasus guru BK selama 1 bulan setelah pemasangan infografis di pintu masuk angka pelanggaran terhadap peraturan sekolah menurun.

\section{Bentuk Pendidikan Karakter di SMP 64}

Bentuk pendidikan karakter dapat diterapkan di lingkungan sekolah maupun dilingkungan keluarga. Oleh karena itu sekolah memegang peranan yang sangat strategis. SMP 64 Jakarta melakukan beberapa kegiatan dalam bentuk pendidikan karakter melalui:

1. Kegiatan belajar mengajar yang sudah tertera dalam silabus setiap mata pelajaran.

2. Kegiatan ekstrakurikuler seperti ; pramuka, rohis, paskibra, dsb.

3. Penerapan aturan tata tertib sekolah seperta; berpakaian rapi, menjaga kebersihan dsb.

Dalam hal tersebut penggunaan infografis yang berisi informasi budaya malu adalah salah satu bentuk dari pendidikan karakter. Berikut nilai-nilai yang dapat diambil sebagai bentuk pendidikan karakter dalam budaya malu yang mengacu pada nilai-nilai pendidikan karakter yang dijabarkan oleh Kementerian Pendidikan Nasional (2010:9-10) adalah: (1) Jujur, (2) Toleransi, (3) Disiplin, (4) Kerja keras, (5) Kreatif, (6) Mandiri,(7) Demokrasi, (8) Semangat kebangsaan, (9) Menghargai prestasi, (10) Bersahabat dan kumunikatif, (11) Cinta damai, (12) Peduli lingkungan, (13) Tanggung Jawab

Budaya malu dengan pendidikan karakter memiliki hubungan yang sangat erat. Suksesnya pendidikan karakter ditandai dengan tingginya budaya malu yang dimiliki seseorang. Dalam hal ini pendidikan karakter bukan hanya menyentuh nilai - nilai normatif namun juga mampu direalisasikan dalam bentuk tindakan nyata. Untuk menuju keberhasilan pendidikan karakter para pendidik perlu menggunakan media yang menarik siswa salah satu contohnya infografis .

\section{SIMPULAN}

1. Budaya malu yang tinggi menandakan kualitas karakter manusia tersebut. Dalam hal ini budaya malu yang dimiliki peserta didik terutama rasa malu akan datang terlambat masih rendah. Jika siswa sering datang terlambat maka proses pembelajaran akan terganggu dan mengakibatkan siswa tertinggal mata pelajaran, sehingga peningkatan kesadaran budaya malu perlu ditingkatkan oleh pihak sekolah memalui kegiatankegiatan yang bersifat positif di sekolah. Dengan peningkatan budaya malu maka nilai - nilai pendidikan karakter akan tumbuh lebih baik di dalam peserta didik, seperti : Jujur, toleransi, disiplin, kerja keras, kreatif, Mandiri, demokrasi, semangat kebangsaan, menghargai prestasi, bersahabat dan kumunikatif, cinta damai, peduli lingkungan, dan tanggung Jawab

2. Keseluruhan kreatif pesan tentang budaya malu yang dipasang di sekolah selama 1 bulan mampu mengubah perilaku siswa yang lebih positif karena mulai meningkatnya budaya malu dan hal tersebut termasuk dalam usaha membangun pendidikan karakter. Hal ini ditandai dengan penurunan persentasi pelanggaran yang dilakukan peserta didik persentase kasus terlambatnya siswa sebanyak $75 \%$, buang sampah sembarangan sebanyak $33 \%$, berbicara kotor $26 \%$, acuh terhadap guru mencapai $100 \%$, dan berpakaian tidak rapi menurun $25 \%$. 
3. Pentingnya media kreatif seperti infografis sebagai media sosialisasi yang mampu menarik perhatian para pelajar. Hal ini bertujuan untuk memudahkan para pendidik dalam proses pembelajaran sekaligus pembentukan karakter yang baik terhadap siswa.

\section{DAFTAR PUSTAKA}

Hamad, I. (2007). Perencanaan Program Komunikasi.Edisi Kedua, Jakarta: Universitas Terbuka.

Ilahi, R., Syahniar, Ibrahim, I. Faktor yang mempengaruhi pelanggaran disiplin siswa dan implikasinya terhadap layanan bimbingan \& konseling. Jurnal Ilmiah Konseling, 2(2),20-25.

Iqbal, C. I. (2014). Budaya Malu Dalam Masyarakat Jepang dan Bugis-Makasar. Walasuji,5(2),315-325

Karakter Bangsa. Jakarta: Balitbang Pusat Kurikulum

Kementerian Pendidikan Nasional. (2010). Pengembangan Pendidikan Budaya Dan

Lankow, J., Ritchie, J., \& Crooks, R. (2014). Infografis Kedasyatan Cara Bercerita Visual. Jakarta: PT Gramedia Pustaka Utama.

Lestari, D. E. (2014). Upaya Menangani Siswa Yang Sering Melanggar Tata Tertib Sekolah Melalui Layanan Konseling Kelompok. JURNAL ILMIAH PENDIDIKAN BIMBINGAN DAN KONSELING, 1(1),24-31

Megawangi, R. (2009). Pengembangan Program Pendidikan Karakter Di Sekolah: Pengalaman Sekolah Karakter. Depok: Indonesia Heritage Foundation

Moleong, L J. (2006). Metode Penelitian Kualitatif. ed. rev. Bandung: PT. Remaja Rosdakarya.

Mulyasa. (2011). Menjadi Guru Profesional (Menciptakan Pembelajaran Kreatif dan Menyenangkan). Bandung: Rosdakarya

Putra, D. P. (2014). Makna Pesan Sosial Dalam Film FREEDOM WRITERS (Analisis Semiotika). Fakultas Ilmu Sosial dan Politik. Universitas Hasanudin. Makasar

Sari, N. (2016). Hari pertama masuk sekolah belasan siswa SMA 3 datang terlambat. $\begin{array}{lllll}\text { Diunduh } & \text { pada } & 1 & \text { September } & 2016\end{array}$ http://megapolitan.kompas.com/read/2016/07/18/07414091/hari.pertama.masuk.se kolah.belasan.siswa.sman.3.datang.terlambat.

Situmorang, H. (2008). Menoleh Budaya Malu Masyarakat Jepang Untuk Lebih Mengenal Indonesia. Sumatra Utara.

Soekanto, S. (2007). Sosiologi suatu Pengantar. Jakarta: P.T.Raja Grafindo.

Susanti, E. (2014). Budaya Malu Cerminan Bagi perempuan melayu. Media Komunikasi Ilmu - Ilmu Sosial dan Budaya, 11(2), 226-236

Takari, M., dkk. (2008). Masyarakat Kesenian di Indonesia. Medan: Studia Kultura, Fakultas Sastra, Universitas Sumatra Utara. 
Tangney, T. (1995). Recent advances in the empirical study of shame and guilt. American Behavioural Scientist. 38, 113-145.

Zaenal, H. (2016). Un smp siswa menyontek hingga tukar lembar jawaban. Diunduh pada 1 September 2016 dari http://daerah.sindonews.com/read/997495/174/un-smpsiswa-menyontek-hingga-tukar-lembar-jawaban-1430800983

Zubaedi. (2011). Desain Pendidikan Karakter: Konsepsi dan Aplikasi Dalam Lembaga Pendidikan. Jakarta: Kencana. 